УДК 78.072(477)-057.634:78.071.1(44)

\title{
ГРАБ У.Б.
}

https://orcid.org/0000-0002-1352-1951

Львівська національна музична академія

імені М. В. Лисенка (Львів, Україна);

ulya.hrab@gmail.com

\section{УКРАЇНА І ЄВРОПА В НАУКОВИХ ПРАЦЯХ МиросЛАвА АНТоновИЧА}

Досліджено праці українського еміграційного музикознавця М. Антоновича. 3'ясовано, що у повоєнні десятиліття, коли українське музикознавство було штучно вилучене 3 міжнародного контексту, М. Антонович провадить активну наукову працю, вивчаючи творчість Жоскена Депре і його сучасників, здійснює велику пошукову роботу в архівах та ідентифікує віднайдені твори. Авторитет вченого у галузі, яка була предметом спільних зацікавлень світової музикології, давав можливість озвучувати питання, пов’язані з українською музичною культурою, на міжнародних форумах.

Ключові слова: еміграційне музикознавство, творчість Жоскена Депре, музика Ренесансу, праці М. Антоновича, українська музика.

Творча та наукова діяльність нашої музичної еміграції доволі часто $\epsilon$ предметом уваги українських музикознавців. Написано ряд наукових праць найширшого жанрово-тематичного діапазону, які мають одну спільну рису: предметом розгляду є музична україністика нашої еміграції у різних ії аспектах композиторському, виконавському, музикознавчому. Цілком зрозуміла засаднича позиція, враховуючи, що саме національна культура була у центрі наукових зацікавлень наших діаспорних діячів, «бо кожен, хто опинився за кордоном, - писав польський поет і публіцист Юзеф Лободовський, - байдуже, чи з власного бажання, чи волею обставин, - стає боржником свого народу, і якщо не сплачує свій борг, як належить, тоді він звичайний утікач, а не емігрант» $[7,318]$. Але огляд українських музикознавчих праць перших повоєнних десятиліть - не лише в еміграції, але й в Україні- свідчить про майже повну відсутність поважних досліджень у галузі західно-європейської, i - ширше - світової музики. Ця проблематика не входила до кола наукових зацікавлень українських музикознавців на материковій Україні та в діаспорі - як у довоєнний період, так і після війни ${ }^{1}$.

Антін Рудницький, автор монографії з історії української музики, перелічуючи українських музикознавців, які вийшли на наукову арену у 50-6о-х роках, зазначає: «Праці цих музикологів, від статей на декілька сторінок до товстих книжок, усі

${ }^{1}$ Праці Стефанії Павлишин - стаття «Творчість Шенберга. 1899-1908 рр.», що з'явилася 1969 року, та книжка «Місячний П'єро» (1972) - були першими науковими дослідженнями 3 проблем сучасної світової музики у Радянському Союзі.

(C) Граб У. Б., 2018 
мають до діла з українською музикою або інколи й російською. Але нема буквально нічого, що торкалося б будь-яких проблем не тільки сучасної західної музики, але навіть і давньої - факт незвичайно характерний, коли взяти під увагу, що російські музикознавці пишуть на ці теми постійно й чимало, та що найважливіше, вільно. Цілковиту відсутність іншої, крім тільки української чи російської тематики в сучасному українському музикознавстві, можна пояснити тільки або недостатнім знанням музики західного світу взагалі, а сучасної зокрема, або також і страхом узагалі писати про будь-що зв'язане з закордонною музикою» $[8,36]$. У цьому контексті особливою є постать Мирослава Антоновича, наукову діяльність якого слід розглядати насамперед у європейському вимірі.

М. Антонович отримав музикологічну освіту у Львівському університеті в 1936 -1939 роках на кафедрі музикології під керуванням польського історика Адольфа Хибінського. Ще під час навчання М. Антоновича цікавила нідерландська музика, якій професор Хибінський присвячував багато уваги: «Мене здавна інтригували у музичних творах старих нідерландських майстрів складні контрапунктичні конструкції, в яких поєднувався інтелектуалізм музичних канонів, символіка чисел 3 красою і багатством звучання, - писав М. Антонович. - Захоплював також своєрідний універсалізм тієї музики, звучання в ній елементів старих церковних григоріанських співів, народного мелосу. Імпонувала архітектоніка великих музичних творів і досконале опрацювання найменших музичних деталей» $[1,446]$. Згодом, уже в еміграції, він продовжив музикологічну освіту в Утрехтському університеті (Голландія), яку завершив у липні 1951 року докторською дисертацією про вплив мотету Benedicta es Жоскена Депре на месу Super Benedicta його сучасників. Про успішний захист його праці (М. Антонович написав її за півроку!) писала і голландська, і українська преса. Тоді професор Альберт Смаєрс (Smijers), відомий голландський спеціаліст з нідерландської музики XV-XVI століть, студентом якого був М. Антонович, сказав: «Вірю, що д-р Антонович зможе знову повернутися на свою Батьківщину і там використати знання, які набув у нашій країні». Однак цьому, на жаль, не судилось здійснитися.

Заснований А. Смаєрсом Інститут музикології багато років був центром, який досліджував не лише нідерландську музичну історію, але й охоплював різні сфери музикознавства. Завдяки його зусиллям там постали бібліотека і фотоархів, в якому зберігалися фотокопї і мікрофільми нідерландської музики XV-XVI століть, а також дублікати знаменитого Віденського фотоархіву австрійської національної бібліотеки $[21,162]$. Серед музикологів школи А. Смаєрса - Е. Різе (Reeser), М. ван Кревел (van Crevel), Г. Нольтеніус (Nolthenius), М. Венте (Vente), Я. ван де Meеp (van der Meer), К. Лінденбург (Lindenburg), М. Антонович та інші вчені, наукова праця яких передовсім була пов'язана з дослідженням нідерландської музики. Взірцем був сам Альберт Смаєрс. Варто згадати хоча б його видання творів Філіпа де Монте, Якоба Обрехта, антологію «Від Окегема до Свелінка» (Van Ockeghem tot Sweelinck), яка представляє всю палітру музичної мови епохи. Саме йому було доручено здійснити повне видання творів Жоскена «Werken van Josquin De Pres», яке він розпочав 1921 року і до 1957 року видав 44 томи.

Дослідження епохи Ренесансу було магістральним напрямком наукових пошуків гуманітарної думки XIX - першої половини XX століття. Дослідники стояли на тих засадах, що «підвалини не тільки мистецького, а й усього духово-звичаєвого життя до початку XX століття й подалі закладено Ренесансом» [4, 94]. Щодо власне 
музичного мистецтва, то саме «усеєвропейський характер» творчості композиторів нідерландської школи мав визначальний вплив на шлях розвитку музики у країнах Західної та Східної Європи до кінця XVI століття. Так, Гайнріх Глареан вважав поліфонію визначних нідерландців інкарнацією (втіленням) музичного ідеалу, а Фрідріх Блюме зазначав, що «їхня творчість, як свідчать рукописні джерела XV століття, а після 1500 року і друковані, мала абсолютну й міжнародну чинність» $[4,115]$. Композиторська техніка нідерландських композиторів удосконалилася настільки, що стала універсальним засобом виразності для втілення будь-яких творчих задумів. Саме тому творчість нідерландської композиторської школи була об’єктом посиленої уваги європейських музикологів і ключем до розуміння шляхів становлення національної музики в рамках єдиної художньої концепції, створеної нідерландцями.

Професор А. Смаєрс високо оцінював науковий потенціал М. Антоновича. Коли 1953 року Утрехтський університет отримав пропозицію вислати свого кандидата на річну стипендію до Гарвардського університету, А. Смаєрс запропонував М. Антоновичу прийняти участь у конкурсі, щоб мати можливість поглибити свої знання 3 музики доби Ренесансу в американського професора Отто Гомбоші. Вже під час навчання у Гарварді, на прохання О. Гомбоші М. Антонович виступив з доповіддю на зборах секції американських музикологів, в якій розглядав проблеми форми й динаміки у месі Жоскена Mater Patris і проводив паралелі між композицією меси і картиною італійського художника Джованні Белліні, намагаючись пов’язати їх із мистецькими, політичними і соціальними течіями Ренесансу. А вільний від лекцій час М. Антонович проводить у бібліотеці, розшукуючи матеріали до української музики, усвідомлюючи все ж, що основна мета поїздки - спеціалізація у галузі західноєвропейської ренесансної музики, на яку залишалося небагато часу. «Часами стає прикро. А відірватися від української музики, від української історії тяжко», - пише він у щоденнику. «Такого багатства матеріялів я дотепер не бачив. I такої ідеальної обстановки для студій до тепер також не бачив (не мав). Як дитина радію кожною знахідкою, кожним реченням, кожним словом про українську музику» $[3,65]$.

А. Смаєрсу М. Антонович завдячує не лише своєю поїздкою до Гарварду, але й подальшим професійним зростанням у галузі дослідження західноєвропейської музики. Свій денний розпорядок він описує в щоденнику: «12 січня 1952. Я почав свої заняття асистента в музикознавчому Інституті. Кілька разів в тиждень треба працювати 12 годин денно, а часом й більше. Від 10 до 16. 30 на університеті, а від 17. 30 до 22-гої постановка голосів і проба хору. Цікаво чи видержу на цих двох посадах. А окрім офіційної праці треба ще писати статті про українську музику, приготовляти реферат на інтернаціональний Конгрес музикологів, приготовляти хор до ювілейного концерту Апостоляту, що має відбутися на другий рік ну й рівночасно приготовляти з хором складну поліфонічну мессу Жоскена Де Пре 16/17 ст. включно 3 григоріанськими співами, що їі маємо співати на ювілею проф. Смайєрса» [3, 12а].

Идеться про Міжнародний конгрес музикологів в Утрехті 1952 року, на який М. Антонович подав тему, пов’язану з багатоголоссям в українській народній музиці. Це викликало певне невдоволення А. Смаєрса, який вважав, що виступати треба 3 темою, над якою М. Антонович саме працював: дослідження впливу стилістики Ренесансу на меси Жоскена і Обрехта (у 1956 році стаття під назвою «RenaissanceTendenzen in den Fortuna-desperata-Messen Von Josquin und Obrecht» вийде друком у журналі Die Musikforschung). Завдання, яке він ставить перед собою у цій праці виявити на багаторівневому порівняльному аналізі двох мес, як саме втілені в них 
елементи, які характеризують новий, ренесансний світогляд: нові структурні i виразові засоби, перетворення старого типу меси на cantus firmus на нову, пародійну. Ці зміни породжували, на думку М. Антоновича, великі можливості для розвитку індивідуального стилю, що є характерною прикметою епохи Ренесансу [13, 5]. Треба зазначити, що вперше у радянському музикознавстві ім'я М. Антоновича згадує Т. Ліванова саме у зв'язку з публікацією цієї статті, вважаючи, що М. Антонович, М. Букофцер і Е. Ловінський були тими трьома дослідниками музичного Ренесансу, які «подали один одному руки, увінчуючи спільними зусиллями досягнення сучасного західного музикознавства у даній галузі» $[5,220]$. Дослідниця називає М. Антоновича одним з кращих знавців творчості Жоскена. Згадуючи першу двотомну монографію про Жоскена Депре німецького музикознавця Гельмута Остоффа, опубліковану в 1962-1965 роках, Т. Ліванова пише: «Чому, здавалося б, не виступити з монографією про Жоскена Депре Мирославу Антоновичу? Однак він віддав перевагу усесторонньому заглибленню в питання приналежності Жоскену деяких, ще дискусійних в цьому сенсі творів» [5, 228].

3 цього часу розпочинається відлік його самостійної наукової праці, яка поєднала два фундаментальні напрямки музикологічної думки - українську церковну музику як найдавніший пласт професійної музики та нідерландську композиторську школу XV-XVI століть, яка втілила у музиці новий художній ідеал свого часу. Наукові праці М. Антоновича перебувають у європейському науковому дискурсі, а західний та східний вектори спрямування його наукових зацікавлень слід розглядати як поділ на Схід і Захід у масштабах Європи за критеріями латинського та візантійського християнства. Якщо східний напрям його студій, а власне давня української музика i іiі візантійська першооснова, на сьогодні доволі добре опрацьований дослідниками, перевидані його праці на цю тему, то західний напрям майже невідомий. I це при тому, що він був єдиним з українських музикознавців не лише в діаспорі, але й на материковій Україні, хто спрямував свої наукові зусилля на дослідження творчості західноєвропейських композиторів доби Ренесансу.

Наукові праці М. Антоновича, які засвідчували високий рівень професіоналізму, здобули визнання світової музикологічної спільноти. До його фахової думки дослухалися світові авторитети, його присутність на світових музикологічних конгресах завжди була бажаною. Високий науковий авторитет у галузі, яка була предметом спільних зацікавлень європейської, а навіть світової музикологічної спільноти, давав можливість на найвищому науковому рівні ставити питання, пов'язані з українською музичною культурою. М. Антонович усвідомлював: щоб зацікавити Європу українською музикою, треба вписати її у європейський духовний контекст, розглядати як частину європейської культурної спадщини, «надати своїм національним інтересам універсального змісту» [7, 328]. Він писав: «Духово належати Заходу значить не наслідувати й достосовувати, а виявляти ці самі прикмети духа, що іх виявляють західні народи <...>. Духово належати до Заходу - значить бути співтворцем, а не імітатором» [2, 181]. Виступи з українською тематикою вимагали певної посвяти треба було самому оплачувати всі витрати, пов'язані з поїздкою, крім того великі труднощі були з матеріалами. Однак, як писав М. Антонович у своєму щоденнику, «така нагода - говорити про українську музику на інтернаціональному конгресі не часто й не кожному трапляється. Совість не позволяє прогаяти таку нагоду» ${ }^{1}$,

${ }^{1}$ Антонович М. Щоденник. Запис від 27 жовтня 1955 року, машинопис, с. 168(1) // Архів М. Антоновича. Інститут церковної музики Українського Католицького Університету (Львів). 
оскільки Захід про Україну знав дуже мало, а у той час він був хіба єдиним, хто мав можливість це зробити. А українці в еміграції плекали україністику для українців, їх замкненість на власній культурі не сприяла взаєморозумінню і діалогу.

Наведемо дуже показовий приклад: у 1971 році у Нью Йорку відбувся Інтернаціональний фестиваль-конференція, присвячений 450-річчю з дня смерті Жоскена Депре. Підготовка цієї масштабної імпрези, яка складалася з наукової, власне музикологічної частини та концертів, на яких звучала музика Жоскена, тривала кілька років. Цей світовий форум тривав п'ять днів, було репрезентовано найважливіші наукові дослідження з проблем музичного Ренесансу та виконавської майстерності відомих колективів. М. Антонович, який був учасником конференції, стримано констатує: «Там нікого з українців не було, та й не думаю, щоби це наших людей дуже цікавило» [6].

Так, на інтернаціональному конгресі в Утрехті 1952 року М. Антонович говорив про багатоголосся в українських народних піснях, у Зальцбурзі 1964 року при «круглому столі» $з$ професором Е. Кошмідером - про проблеми форми та гласів в ірмосах українських та візантійських, у Оксфорді на інтернаціональному музикознавчому конгресі 1955 року темою виступу були українські літургійні мелодії. М. Антонович згадує присутніх на цьому конгресі «старих, світової слави учених i молодих адептів музикознавства»- проф. (Е. Веллеша, Л. Шраде, К. Г. Феллерера, Г. Альбрехта і багатьох інших, 3 якими у нього встановилися дружні стосунки. Вчений зазначає: «Круг моїх знайомих <...> дуже поширився. Виявилося, що дуже багато найвизначніших музикологів читали мою дисертацію про Жоскена де Пре $<\ldots>$, i це дуже улегшувало робити нові знакомства» ${ }^{1} .3$ багатьма відомими у світі музикологами (зокрема, Густавом Різом, Яапом ван Бентемом, Гельмутом Остоффом, Вілемом Елдерсом, Мілошем Веліміровичем та ін.) М. Антоновича поєднували багаторічні приятельські стосунки та наукова праця.

Дослідження творчості одного 3 найяскравіших представників музичного Ренесансу Жоскена Депре приносить М. Антоновичу визнання світової музикологічної спільноти і членство у Міжнародному музикологічному товаристві та Національній музикознавчій спілці Нідерландів. Творчість цього композитора була предметом доповідей на Інтернаціональному конгресі в Нью-Йорку у 1961 році та Міжнародному фестивалі-конференції, а також на засіданні інтернаціональної комісії для нового видання творів Жоскена Депре в Ганновері (США) у 1977 році.

1957 року помирає Альберт Смаєрс, не завершивши видання творів Жоскена, над яким працював понад 35 років. Завершити його доручили М. Антоновичу, який до 1969 року публікує (з 1965 року за допомогою Вілема Елдерса) ще 4 меси, 38 мотетів і 34 світські твори і закінчує перше новітнє видання творів композитора. Голландський музиколог Яап ван Бентем - відомий фахівець 3 дослідження нідерландської музики, один з редакторів Нового видання творів Жоскена (NJE) - вважав, що для Ради музикологічної спільноти Нідерландів, яка займалася публікацією видань А. Смаєрса, досвід М. Антонович зробив його ідеальним наступником для завершення роботи над виданням творів Жоскена. Цьому передувала дуже кропітка робота з ідентифікації творів композитора та перекладення їх зі старої нотації на сучасне нотне письмо.

3 цієї нагоди німецький музиколог Гельмут Остофф напише у листі до M. Антоновича: «Хотів би щиро привітати Bac із тим, що Vereeniging [Нідерландське

${ }^{1}$ Антонович М. Щоденник. Запис від 27 червня 1955 року, машинопис, с. 168(4) // Архів М. Антоновича. Інститут церковної музики (Львів). 
королівське товариство історії музики] доручило Вам почесне завдання продовжити видавати «Werken van Josquin des Prez», чудову працю всього життя нашого незабутнього колеги, Альберта Смаєрса. Бажаю Вам при виконанні цього гарного, але важкого завдання великих успіхів і тішуся, що випуски незабаром знову відновляться. Якщо у Вас будуть якісь побажання чи запитання, я завжди охоче до Ваших послуг» [16]. Вони активно обмінюються фотокопіями рукописів творів Жоскена і думками з приводу їх автентичності, які свідчать про глибоке розуміння стилістики композитора: «Стосовно Magnificat iз Ростоцького рукопису, моє сумління ще не цілком спокійне, - пише М. Антонович. - 3 одного боку - майже мелодична скромність, щоб не сказати вбогість, контрапунктових голосів, яку дуже важко собі уявити в Жоскена, а з іншого - досконала, збалансована структура, з кількома цікавими деталями, які таки нагадують Жоскена. Але це - суто моє перше враження після введення в партитуру фотокопій, які я нещодавно від Вас отримав» [18].

У питаннях ідентифікації творів М. Антонович мав авторитет серед фахівців. Так, Ф. Блюме, згадуючи мотет «Sancti Dei omnes» (який А. Смаєрс і М. Антонович спочатку вважали твором Жоскена і включили його у повне зібрання творів композитора, а у 1959 році М. Антонович, зробивши глибокий стилістичний аналіз твору, визначив, що композиція належить Жану Мутону1), пише: «Якщо такий видатний фахівець по Жоскену, як професор Антонович, був «обманутий» мотетом, який в різних джерелах записаний під різними іменами, то що ж тоді в подібних питаннях може припустити неспеціаліст?» $[18,21]$. Про вагомість думки М. Антоновича у питаннях ідентифікації творів Жоскена свідчить, зокрема, i його листування 3 Гельмутом Остоффом, який під час роботи над своєю монографією про Жоскена неодноразово звертається по допомогу до нього у питаннях достовірності творів та правильної їх інтерпретації: «Чи Ви відкрили ще якісь прогалини в моєму каталозі мотетів? - пише Остофф у одному з листів до М. Антоновича. - Я вдячний Вам за кожну вказівку» [17]. 2011 року у своїй праці «Жоскен де Пре та його музична спадщина» В.Елдерс називає імена близько 20-ти композиторів, які використовували музичний матеріал з творів Жоскена у своїй творчості, зокрема, Лупуса Хеллінка, П’єра Мулю, Карпантра, Антуана де Февана, Жоржа де ля Геля, Філіпа дель Монте і навіть Палестріну $[19,39]$. А наслідували стиль великого майстра і його сучасники, і послідовники на всьому обширі Західної та навіть Східної Європи!

Наприкінці 60-х років з'являються друком ще три праці, присвячені нідерландській музиці XV-XVI століть - про мотети Жоскена [11], меси Mater Patris Жоскена (1967) [10] і Лупуса Хеллінка (1969) [9]. Водночас М. Антонович працює викладачем в Інституті музикології Утрехського університету. Яап ван Бентем, який навчався у нього, пригадував, як протягом 1962-1964 років прослухав курс лекцій по білій мензуральній нотації кінця XV - початку XVI століття. Як матеріали М. Антонович використовував детально розроблений фотоархів А. Смаєрса цього періоду. Якщо до нього звертались за порадою, дружня відповідь М. Антоновича була здебільшого поєднанням ймовірностей: завжди потрібно звертати увагу на невідповідності або потенційні помилки у переданій нотації. Він досліджував зі студентами проблеми у горизонтальній площині. Протягом цього періоду М. Антонович давав уроки з органної і лютневої табулятури, а також керував школою церковного співу Scola Cantorum.

\footnotetext{
${ }^{1}$ Жан Мутон (Mouton) - бл. 1459 - 1522) - французький композитор.
} 
У 1971 році на Міжнародному фестивалі-конференції, присвяченому 450-літтю від дня смерті Жоскена Депре, М. Антонович виступив з доповіддю про мотет Illibata Dei Virgo, який, за припущенням вченого, міг бути свого роду мелодичним автопортретом Жоскена [12]. М. Антонович звертає увагу на цифрову символіку, за допомогою якої композитор зашифрував своє ім'я в cantus firmus мотету. Але найцікавішими $\epsilon$ його спостереження про мелодичну спорідненість мотету, особливо його першої частини, з іншими творами Жоскена. М. Антонович наводить численні приклади, які підтверджують його висновок: «У цій композиції, в якій ім'я Жоскена сховане в акровірші й численних cantus firmus, композитор свідомо дозволяє дослідити його мелодичну, контрапунктичну та cantus firmus техніку, уживши разом елементи 3 різних творів. Цей твір можна подавати як демонстрацію його стилю» $[12,558]$.

До проблем, пов'язаних зі стилістикою цього мотету, його створення, дослідники поверталися неодноразово, щоразу посилаючись на працю М. Антоновича. Зокрема, в 1997 році з'явилася стаття Леслі Куттерхама (Clutterham) під назвою «Автобіографічні конструкції в мотеті Жоскена Illibata Dei virgo nutrix: докази пізнішого знайомства» [15], в якій знову ж згадується концепція М. Антоновича про мотет як автобіографічний «мелодичний» портрет композитора. Стаття узгоджує аналітичні висновки в контексті цілого мотету та пропонує деякі нові теорії щодо дати та обставин його написання, а також біографічну інформацію про композитора. Критикуючи М. Антоновича за те, що його висновки опираються на аналіз лише першої частини мотету, автор наприкінці змушений констатувати, що Illibata Dei virgo nutrix представляє надзвичайно складний рівень взаємозалежних музичної та позамузичної організацій і завершує свою статтю цитатою М. Антоновича: «текст і музика Illibata Dei virgo nutrix, незалежно від їхнього екстра-музичного імпорту, $\epsilon$ цілком такою, як Жоскен. У цьому контексті «це музичний автопортрет Жоскена, в кожному мелодичному ході і в тональному забарвленні кожного акорду ми впізнаємо багату креативність думки, що належить найвеличнішому з найбільших в культурній історії Європи» [15].

На цьому Міжнародному фестивалі-конференції, присвяченому 450-річчю від дня смерті Жоскена Депре, було прийнято рішення про підготовку другого, оновленого видання творів композитора (New Josquin Edition), оскільки було здійснені нові джерелознавчі дослідження і використані нові методики у вивченні музичних джерел. Підготовку до цього видання розпочала міжнародна команда музикологів, яка формувала нові принципи, які мали забезпечити музичну і наукову цінність нової редакції. «За кілька років до завершення видання [Werken van Josquin des Prez У.Г.], стало зрозуміло, що його редакційна техніка більше не відповідає стандартам, які встановили найновіші музикологічні дослідження, - писав В. Елдерс. - Щоб запобігти втраті однорідності, М. Антонович все-таки віддав перевагу методу А. Смаєрса для завершення видання Жоскена» $[20,20]$. Тому М. Антоновича як представника «старої» методологічної школи А. Смаєрса до нової редакційної колегії не включили.

Нове видання мало базуватися на головних пунктах: опрацювання нових джерел, проблеми їх автентичності, методи транскрипції, відбір пріоритетних джерел, їх оцінка і систематизація. Поки тривали організаційна підготовка нового видання (перший том NJE був опублікований лише 1985 року), М. Антонович поступово відійшов від цієї теми і продовжив роботу над публікаціями про українську музику.

Наукова спадщина М. Антоновича, присвячена дослідженню творчості Жоскена Депре та його сучасників, стала підгрунтям «жоскенознавства», яке в 50-х роках 
тільки набирало сили (після смерті А. Смаєрса М. Антонович був єдиним серед його студентів, який написав дисертацію, що стосувалася творчості Жоскена. Саме тому Рада музикологічного товариства Нідерландів (Vereniging voor Nederlandse Muziekgeschiedenis) доручила йому продовжити видавничу працю А. Смаєрса, бо була впевнена у тому, що М. Антонович збереже його традиціі, і це гарантувало їй якість завершення «Werken van Josquin des Prez». На думку авторитетних фахівців, зокрема, Я. ван Бентема, видання А. Смаєрса залишається видатним проектом, що відображає стиль та досягнення музикологічної науки до початку Другої світової війни, а проблема М. Антоновича полягала в тому, що його праця була завершена у новий період, де панувало нове покоління вчених.

Авторитет М. Антоновича у цій науковій галузі забезпечив довіру європейської музикологічної спільноти до його східно-європейського напрямку досліджень, а власне української музики. Завдяки цьому у перші повоєнні десятиліття, в роки холодної війни на міжнародних музикологічних форумах українська музика повернулася у властивий для неї європейський контекст.

\section{СПИСОК ВИКОРИСТАНОЇ ЛІТЕРАТУРИ ТА ДЖЕРЕЛ}

1. Антонович М. Між двома війнами: Спогади: У двох частинах / упор. і підготував до друку О. Долгий. Ч. 2. Київ, 2003. 538 с.

2. Антонович М. Українська церковна музика й органи // Musica sacra. Збірник статей з історії української церковної музики. Львів, 1997. С. 165-182.

3. Антонович М. Щоденник. Автограф та авторизований машинопис // Архів М. Антоновича. Інститут церковної музики Українського Католицького Університет (Львів).

4. Блюме Ф. Ренесанс [Відродження] // Епохи історії музики в окремих викладах. Перекл. та ред.-упор. Ю. Семенов. Одеса, 2003. С. 92-145.

5. Ливанова Т. Проблема Ренессанса в современном западном музыкознании // Из истории музыки и музыкознания за рубежом. Москва, 1981. С. 181-231.

6. Лист М. Антоновича до П. Маценка від 25 жовтня 1973 року // Архів Осередку Української Культури і Освіти у Вінніпезі. Фонд П. Маценка. авторизований машинопис, 1 арк.

7. Лободовський Ю. Українська еміграційна література // Простір свободи: Україна на шпальтах паризької «Культури». Київ : Критика, 2005. С. 309-329. $406 \mathrm{c}$.

8. Рудницький А. Українська музика: Історично-критичний огляд. Мюнхен, 1963.

9. Antonowycz M. Das parodieverfahren in der missa Mater Patris von Lupus Hellinck // Renaissance-muziek 1400-1600 Donum natalikum Rene Bernard Lenaerts. Leuven: Katholieke universiteit seminarie voor muziek-wetenschap, 1969, s. 33-38.

10.Antonowycz M. Die Missa Mater Patris von Josquin des Pres // Tijdschrift van de vereniging voor nederlandse muziek geschiedenis, XX (1967/4). Amsterdam, pp. 206-225.

11.Antonowycz M. Zur Autorschaftsfrage der Motetten «Absolve, quaesumus, Domine» und «Inter natos mulierum»// Tijdschrift van de vereniging voor nederlandse muziek geschiedenis, XX. (1966/3). Amsterdam, pp. 154-169.

12.Antonowytch M. Illibata Dei Virgo: A Melodic Self-Portrait of Josquin des Prez. London: London Oxford University Press, 1976, pp. 545-559.

13.Antonowytsch A. Renaissance Tendenzen in den Fortuna - desperata - Messen von Josquin und Obrecht // Die Musikforschung. 1957, IX. P. 5.

14.Blume F. Josquin des Prez: the man and the music // Josquin des Prez. Edited by Edward E. Lowinsky. London : Oxford University Press, 1976. 
15.Clutterham L. Auobiographical Constructions in Josquin's Motet Illibata Dei virgo nutrix: Evidence for a Later Dating // American Musicological Society, April 1997. URL: http://www.calstatela.edu/sites/default/files/centers/Wagner/documents/Josq.pdf (дата звернення: 20. XI. 2017)

16.Der Brief vom H. Osthoff an M. Antonowycz. 20 September 1958, Frankfurt a. M. // Архів М. Антоновича. Інститут церковної музики Українського Католицького Університет (Львів). Авторизований машинопис, 1 арк.

17. Der Brief vom H. Osthoff an M. Antonowycz. 5 Oktober 1958, Frankfurt a. M. // Apxiв М. Антоновича. Інститут церковної музики Українського Католицького Університет (Львів). 1 арк.

18.Der Brief vom M. Antonowycz an H. Osthoff. 13 April 1959, арк. 1 // Архів М. Антоновича. Інститут церковної музики Українського Католицького Університету (Львів). Авторизований машинопис, 2 арк.

10 Elders W. Josquin des Prez en zijn muzikale nalatenschap. Hilversum : Uitgeverij Verloren, 2011.256 p.

20.Elders W. Report of the first Josquin meeting // Tijdschrift van de Vereniging voor Nederlandse Muziekgeschiedenis, XXIV-1. Amsterdam 1974. C. $20-82$.

21.Reeser E. Musikwissenschaft in Holland // Acta Musicologica, vol. XXXII. Basel : Bärenreiter-Verlag, 1960. C. 160-174.

\section{REFERENCES}

1. Antonowych, M. (2003). Mizh dvoma vijnamy`: Spogady`: U dvox chasty`nax [Between the two wars: Memories: In two parts]. Upor. i pidgotuvav do druku Oleg Dolgy`j. Ch. 2. Kyiv, 538 p. [in Ukrainian].

2. Antonowych, M. (1997). Ukrayins`ka cerkovna muzy`ka j organy`. [Ukrainian Church Music and Organs]. In: Musica sacra. Zbirny`k statej z istoriyi ukrayins`koyi cerkovnoyi muzy`ky`. L`viv, pp. 165-182. [in Ukrainian].

3. Antonowych, M. Shhodennyk [Diary]. Avtograf ta avtory`zovany`j mashy`nopy`s. Arxiv M. Antonowycha. Insty`tut cerkovnoyi muzy`ky` Ukrainskoho Katolytskoho Universytetu (L`viv). [in Ukrainian].

4. Blume, F. (2003). Renesans [Renaissance ]. In: Epoxy` istoriyi muzy ky` v okremy`x vy`kladax. Perekladach ta redaktor-uporyadny`k Yurij Semenov, Odesa 200. pp. 92-145. [in Ukrainian].

5. Ly`vanova, T. (1981). Problema Renessansa v sovremennom zapadnom muzykoznanyy [The Renaissance Problem in Modern Western Musicology]. In: Yz y story y` muzyky $y^{`}$ muzykoznany ya za rubezhom. Moskva 1981, pp.181-231. [in Rusian].

6. Lyst M. Antonovycha do P. Matsenka vid 25 zhovtnia 1973 roku [M. Antonovych's letter to P. Matsenko, November 25, 1973]. Arkhiv Oseredku Ukrainskoi Kultury i Osvity u Vinnipezi. Fond P. Matsenka. avtoryzovanyi mashynopys, 1 ark. [in Ukrainian].

7. Lobodovs`ky`j, Yu. (2005). Ukrayins`ka emigracijna literatura [Ukrainian emigration literature]. In: Prostir svobody`: Ukrayina na shpal `tax pary`z 'koyi «Kul`tury`». Kyiv: Kry`ty`ka, pp. 309-329. [in Ukrainian].

8. Rudny`cz`ky`j, A. (1963). Ukrayins`ka muzy`ka: Istory`chno-kry`ty`chny`j oglyad [Ukrainian music: Historic-critical review. ]. Miunkhen [in Ukrainian].

9. Antonowycz, M. (1969). Das parodieverfahren in der missa Mater Patris von Lupus Hellinck. In : Renaissance-muziek 1400-1600 Donum natalikum Rene Bernard Lenaerts. Leuven: Katholieke universiteit seminarie voor muziek-wetenschap, pp. 33-38. [in Deutsch]. 
10. Antonowycz, M. (1967). Die Missa Mater Patris von Josquin des Pres. In : Tijdschrift van de vereniging voor nederlandse muziek geschiedenis, XX (1967/4). Amsterdam, pp. 206-225. [in Deutsch].

11. Antonowycz, M. (1966). Zur Autorschaftsfrage der Motetten «Absolve, quaesumus, Domine» und «Inter natos mulierum». In: Tijdschrift van de vereniging voor nederlandse muziek geschiedenis, XX. (1966/3). Amsterdam, pp. 154-169. [in Deutsch].

12. Antonowytch, M. (1976). Illibata Dei Virgo: A Melodic Self-Portrait of Josquin des Prez. London : London Oxford University Press, pp. 545-559. [in English].

13. Antonowytsch, A. (1957). Renaissance Tendenzen in den Fortuna - desperata - Messen von Josquin und Obrecht. In: Die Musikforschung, IX, p. 5. [in Deutsch].

14. Blume, F. (1976). Josquin des Prez: the man and the music. In : Josquin des Prez. Edited by Edward E. Lowinsky. London : Oxford University Press,1976. [in English].

15. Clutterham L. Auobiographical Constructions in Josquin's Motet Illibata Dei virgo nutrix: Evidence for a Later Dating // American Musicological Society, April 1997. Availale at: http://www.calstatela.edu/sites/default/files/centers/Wagner/documents/Josq.pdf (acessed 20. XI. 2017). [in English].

16. (1958). Der Brief vom H. Osthoff an M. Antonowycz. 20 September, Frankfurt a. M. Arkhiv M. Antonovycha. Instytut tserkovnoi muzyky UKU, Lviv. Avtoryzovanyi mashynopys, 1 ark. [in Deutsch].

17. (1958). Der Brief vom H. Osthoff an M. Antonowycz. 5 Oktober, Frankfurt a. M. Arkhiv M. Antonovycha. Instytut tserkovnoi muzyky UKU, Lviv. 1 ark. [in Deutsch].

18.18. (1959). Der Brief vom M. Antonowycz an H. Osthoff. 13 April. Arkhiv M. Antonovycha. Instytut tserkovnoi muzyky UKU, Lviv. Avtoryzovanyi mashynopys, 1 ark. [in Deutsch].

19.Elders, W. (2011). Josquin des Prez en zijn muzikale nalatenschap. Hilversum : Uitgeverij Verloren, 256 p. [in Netherland].

20. Elders, W. (1974). Report of the first Josquin meeting. In : Tijdschrift van de Vereniging voor Nederlandse Muziekgeschiedenis, XXIV-1. Amsterdam, pp. 20-82. [in English].

21. Reeser, E. (1960). Musikwissenschaft in Holland. Acta Musicologica, vol. XXXII. Basel : Bärenreiter-Verlag, pp. 160-174. [in Deutsch].

Стаття надійшла до редакиії 12.12.2017 p..

\section{Ulyana Hrab}

https://orcid.org/0000-0002-1352-1951

Mykola Lysenko Lviv National

Music Academy (L'viv, Ukraine);

ulya.hrab@gmail.com

\section{UKRAINE AND EUROPE IN RESEARCH PAPERS OF MYROSLAW}

\section{ANTONOWYCH}

The relevance of the study is determined by the need to reveal the significance of Myroslaw Antonowych's musicalogical activity in the context of the culturalhistorical period (50-70 years). Main objective(s) of the study. The purpose of the research is to analyze the scientific work of the Ukrainian musicologist Myroslaw Antonowych, devoted to the musical culture of the Renaissance, in particular the works of Josquin des Prez and to find out its significance for the introduction of Ukrainian studies in the world of musicology discourse. In the 50-ies in Utrecht (the Netherlands) he 
initiates research combining two fundamental trends of musicological thought - a Ukrainian church music as the oldest basis of professional music and the Netherlandish School of XV - XVII century that embodied a new artistic ideal for those days. $t$ was ascertained that in the postwar decades, when Ukrainian musicology was internationally prohibited for political motives, M. Antonowych conducted active scientific researches of Josquin des Prez's artwork and his contemporaries, by specifying found works of Josquin des Prez. A sustained contribution of M. Antonowych into the first publication of works of Josquin des Prez that was launched in 1935 by a Dutch musicologist Albert Smijers was highlighted. A major scientific authority in the field that was a subject-matter of joint interests of the world musicology gave an opportunity to raise issues related to Ukrainian music culture on international forums.

Methodology. During the research a historiographic method was used while processing sources in the archives of M. Antonowych (Institute of Church Music of the Ukrainian Catholic University (Lviv)), the analytical method used in the analysis and comprehension of his scientific works, the inductive method used to reproduce an integral depiction of the musical activity of M. Antonowych, basing the analysis of some of its components.

Results and conclusions. It has been established how important was the contribution of Antonowych to the studies of music of the Western European Renaissance, in particular, the work of Josquin des Prez. A major scientific authority in the field that was a subject-matter of joint interests of the world musicology gave an opportunity to raise issues related to Ukrainian music culture on international forums.

Keywords: emigratory musicology, creative work of Josquin des Prez, Renaissance music, works of M. Antonowych, Ukrainian music.

\section{Граб У. Б.}

https://orcid.org/0000-0002-1352-1951

Львовская национальная музыкальная академия

имени Н. В. Лысенко (Львов, Украина);

ulya.hrab@gmail.com

\section{УКРАИНА И ЕВРОПА В НАУЧНЫХ ИССЛЕДОВАНИЯХ МИРОСЛАВА АнтоновИЧА}

Актуальность исследования обусловлена необходимостью раскрыть значение музыковедческой деятельности Мирослава Антоновича в контексте культурно-исторической эпохи (50-70 годов). Целью исследования является анализ научной деятельности М. Антоновича, посвященной музыкальной культуре Ренессанса, в частности Жоскена Депре, и ее значения для введения музыкальной украинистики в мировой музыковедческий дискурс. В 50-х годах в Утрехте (Голландия) он начинает исследования, которые объединили два фундаментальных направления музиковедения - украинскую церковную музыку как древнейший пласт профессиональной музыки и нидерландскую композиторскую школу XV-XVI веков, воплотившую в музыке новый художественный идеал своего времени. Установлено, что в послевоенные десятилетия, когда украинское музыковедение искусственно, по идеологическим причинам было изъято из международного контекста, М. Антоно- 
вич ведет активную научную работу, изучая творчество Жоскена Депре и его современников, осуществляет большую поисковую работу в архивах, идентифицируя найденые произведения Жоскена Депре. Выявлено большой вклад М. Антоновича в первое издание произведений Жоскена Депре, основанное нидерландским музыковедом Альбертом Смайерсом.

В исследовании был использован источниковедческий метод при работе с материалами, которые находятся в архиве М. Антоновича (Институт церковной музыки Украинского Католического Университета (Львов); а н а л и т и че с к и й метод при анализе и осмыслении научных трудов М. Антоновича, индукти вный метод для восстановления полной картины его музыковедческой деятельности методом анализа ее отдельных компонентов. В выводах исследования выяснено важный вклад М. Антоновича в исследование музыки западноевропейского Ренессанса, в частности Жоскена Депре. Высокий научный авторитет в области, которая была предметом совместных интересов мировой музыкологии, позволял озвучивать вопросы, связанные с украинской музыкальной культурой, на международных форумах.

Ключевые слова: эмиграционное музыковедение, творчество Жоскена Депре, музыка Ренессанса, исследования М. Антоновича, украинская музыка. 